(C) 2018

\author{
Макесва О. В., аспірант \\ (науковий керівник - доктор економічних наук Самойлік М.С.)
}

Полтавська державна аграрна академія

\title{
ЕКОЛОГІЧНЕ ОБГРУНТУВАННЯ ФОРМУВАННЯ РЕГІОНАЛЬНОЇ ЕКОЛОГІЧНОЇ МЕРЕЖІ ДЛЯ ВИЗНАЧЕННЯ НАПРЯМІВ ФУНКЦІОНУВАННЯ ПРИРІЧКОВИХ ЗОН. ТЕОРІЯ І ПРАКТИКА
}

\section{Рецензент - доктор сільськогосподарських наук, професор П. В. Писаренко}

\begin{abstract}
Сучасний стан природних ландшафтів України лише частково відповідає критеріям віднесення їх до Всеєвропейської екологічної мережі. Відмічається погіршення умов забезпечення територіальної єдності ділянок із природними ландшафтами, щзо ускладнюють, а інколи унеможливлюють просторові проиеси біологічного обміну, притаманні жсиій природі. За допомогою оглядових методів досліджено та описано місие, роль і сучасний стан розвитку регіональних екологічних мереж у рамках виконання загальнодержавної програми формування начіональної екологічної мережі Украӥни на 2000-2015 рр. Висвітлено основні приниипи формування екомережі та їх застосування на різних етапах реалізації програми. Запропоновано модель розширення екологічної мережі за рахунок функиіонування прирічкових зон, прийнявши екосистему Прирічкового парку м. Полтава екологічно-стабільною функиіонуючою територією в умовах міста, де важливим є не тільки збереження біоценозу, a $i$ резервування та подальше надання статусу як типово-унікальній екосистемі на основі показників стабільності.
\end{abstract}

Ключові слова: екологічна мережа, біорізноманіття, збереження видів, прирічкова територія, агроландшафт, екологічно стабільні території, стійкий розвиток, екологічна політика.

Постановка проблеми. Наша планета - це цілісна, структурована, унікальна, саморегулююча та самовідновлювана біотична система. За сутністю це історія нескінченного розвитку різноманіття форм і функцій життя як єдиного, цілісного, унікального планетарного явища. Вся різноманітність форм живого називається біорізноманіттям, яке відмінно функціонує в умовах екологічно стабільних територій.

Останнім часом питання збереження біорізноманіття стає все актуальнішим. Тому важливою $\epsilon$ розробка та впровадження програми розбудови екологічної мережі як підтримка Загальнодержавної програми формування національної екологічної мережі України на 2000-2015 роки, в основу якої покладено збереження існуючих видів в умовах відтворення екологічно-стабільних територій.
Сучасний стан природних ландшафтів України лише частково відповідає критеріям віднесення їх до Всеєвропейської екологічної мережі. Відмічається погіршення умов забезпечення територіальної єдності ділянок із природними ландшафтами, що ускладнюють, а інколи унеможливлюють просторові процеси біологічного обміну, притаманні живій природі [7].

3 метою наукового забезпечення виконання заходів із формування національної екологічної мережі Програмою передбачається проведення фундаментальних і прикладних досліджень, спрямованих на розробку рекомендацій і методів щодо збереження та відтворення ландшафтного різноманіття, в тому числі проведення оцінки сучасного стану природних ландшафтів, обгрунтування найбільш ефективних заходів, що забезпечать збалансоване і невиснажливе використання їх природних ресурсів, інвентаризацію природних комплексів та їх компонентів, організацію ведення кадастрів природних ресурсів та моніторингу довкілля у межах національної екологічної мережі, створення відповідних банків даних і геоінформаційних систем [2].

Аналіз останніх досліджень і публікацій, у яких започатковано розв'язання проблеми. Питання формування екомережі не є чимось абсолютно новим. Адже ще В. В. Докучаєв [1], який очолював особливу експедицію у 1892-1899 рр., висловив ідею раціональної організації території, тобто оптимального співвідношення між орними землями, луками, лісами і водними ресурсами. Вже тоді виникали серйозні проблеми, хоча такої шкоди навколишньому середовищу, як нині, завдано ще не було. Ще на початку XX ст. В. І. Вернадський висловлював думку про те, що людина перетворюється в основну геологоутворюючу силу Планети. Сьогодні монополізм людини як біологічного виду має надзвичайний прояв. Тому екологічні кризи в історії людства неминучі. Вони обертаються перебудовою не лише біосфери, а й усієї верхньої оболонки планети, стають епохальними подіями історії Землі [5]. 


\section{СТОРІНКА МОЛОДОГО ВЧЕНОГО}

Зміст ідеї створення національної екологічної мережі полягає в тому, щоб забезпечити сталий, екологічно збалансований розвиток України; досягти реальної охорони навколишнього природного середовища; задовольнити сучасні та перспективні економічні, соціальні, екологічні, культурні та інші інтереси суспільства [8].

Мета дослідження - проаналізувати місце, роль i сучасний стан розвитку регіональних екологічних мереж у рамках виконання загальнодержавної програми формування національної екологічної мережі України на 2000-2015 pp.

Завдання дослідження - розглянути ландшафти прирічкових зон з точки зору функціонування екологічно стабільних територій та визначити можливі шляхи розвитку екологічної мережі на основі функціонування існуючих компонентів середовища.

Матеріали та методи досліджень. Ідея формування екологічної мережі $є$ інтегральною у справі збереження природного середовища, оптимізації ландшафтів, збереження генофонду живої природи, формування сприятливих умов для життєдіяльності людини.

Терміном «екомережа» позначають сукупність ділянок відносно недоторканої природи, де тварини і рослини практично позбавлені впливу людини (ядра екомережі), та шляхів, якими ці ділянки сполучаються між собою (екологічні коридори). Так, наприклад, ядрами екомережі можуть бути два ліси, а коридором - річка, що протікає між ними. Руслом і берегами річки тварини зможуть пересуватися $з$ однієї ділянки лісу в інший. Це приклад локальної мережі; такі системи поєднуються у більші, котрі в свою чергу формують глобальну екомережу, що охоплює всю планету. Територія екологічної мережі - це свого роду данина, це той мінімум, який ми лишаємо живим істотам Землі, i який обов'язково має бути звільненим від впливу господарської діяльності людини [3]. Програма формування національної екологічної мережі України передбачає виділення ключових районів, екологічних коридорів, відновлюваних і буферних територій з урахуванням біогеографічних зон; відбір збережених екосистем і ландшафтів, типів середовищ існування видів (екотонів) регіонального i національного значення. Останніми роками постерігається значний інтерес до ландшафтів та їхньої охорони 3 огляду на деструктивну та неконтрольовану їхню зміну, а також процес ландшафтної гомогенізації $[9,10]$. Екологічна мережа буде формуватися також завдяки природно-відновним територіям - залишкам первинних або вторинних екосистем із певним потенціалом видів. Природновідновні території будуть створювати і в сільськогосподарських ландшафтах шляхом ренатураліза- ції (консервації) орних земель, передусім, еродованих. Важливими складовими регіональної екомережі $є$ ліси та землі водного фонду.

Свропейська програма формування екомережі передбачає: обгрунтування критеріїв для виділення ключових районів, екокоридорів, відновлювальних районів і буферних зон з урахуванням біогеографічних зон, відбір екосистем, типів середовищ існування «біотопів», видів і ландшафтів європейського значення, визначення конкретних ділянок для збереження, покращання або відновлення екосистем, середовищ існування, видів та їхнього генетичного різноманіття, а також ландшафтів європейського значення, опрацювання директив, які забезпечать максимально послідовне та ефективне здійснення заходів щодо створення екомережі [1].

Одним із важливих чинників оцінки існуючого використання ландшафтів $є$ показник екологічної стабільності території. Рівень екологічної стабільності конкретної території земельно-господарських структур зумовлює прийняття управлінських і проектних рішень щодо раціонального використання та охорони земель, а також впливає на розробку стратегії розвитку сільських територій [4].

Міжнародні екологічні зобов'язання, екологічна політика, екологічна глобальна інтеграція, екологічна безпека набули сьогодні пріоритетного значення як у державній, так і в міжнародній політиці України. Реальний екологічний стан в Україні характеризується як кризовий, суттєве поліпшення якого потребує високої екологічної компетенції службовців усіх секторів державного управління.

Результати досліджень. 3 метою підвищення рівня екологічної освіти, виховання, культури населення, активізації його участі у виконанні заходів 3 формування національно екологічної мережі Програмою передбачається: сприяння у створенні нових і залученні існуючих громадських екологоекспертних центрів до діяльності, спрямованої на усвідомлення суспільством значення проблеми збереження ландшафтного різноманіття, середовищ існування видів рослин і тварин; розроблення та впровадження пропозицій щодо участі населення у виконанні заходів із формування національної екологічної мережі, у тому числі юнацтва та молодого покоління, з урахуванням досвіду позашкільної екологічної освіти 3 питань формування екологічної культури та забезпечення широкої інформованості з проблем охорони довкілля.

Озеленені території i зелені насадження в міському середовищі виконують кілька різних функцій, в тому числі екологічні, соціальні, економічні, містобудівні, історико-культурні та ін. Доказом того, що всі функції зелених зон у рівній мірі важливі для громадян, є те, що кількість і якість 


\section{СТОРІНКА МОЛОДОГО ВЧЕНОГО}

зелених насаджень - визнаний міжнародний індикатор відповідності міст принципам стійкого розвитку. Стійкий розвиток - це такий розвиток суспільства, який задовольняє три типи цілей - економічну, соціальну та екологічну, а також утримує розвиток суспільства в рамках, в яких наявні ресурси використовуються 3 урахуванням потреб майбутніх поколінь. Якщо ж говорити про роль зелених насаджень не лише для суспільства, а в комплексі, то на перше місце, безумовно, висуваються їхні екологічні функції. До екосистемних функцій озеленених територій належить і те, що фактично вони є єдиними міськими територіями, поверхня яких не вкрита асфальтом, каменем і будівлями. Таким чином, лише тут можливе проникнення атмосферних опадів у грунт, що 3 одного боку знижує кількість ливневих стоків, які потрапляють у міську каналізацію, а $з$ іншого боку - необхідне для підтримання рівня грунтових вод і нормального живлення тих же дерев та кущів. Зелені зони в місті як у складі потужних паркових насаджень, так і в формі насиченого окремо розташованими деревами вуличного озеленення $є$ важливою складовою поняття «висока якість життя». На це чітко вказує аналіз цін на нерухомість і результати соціологічних досліджень, опитувань. Міська природа оточує жителя міста більшу частину його життя і $є$ для нього повсякденним природним фоном. Зелені зони в місті грають роль зв'язуючої ланки з природою і забезпечують «відчуття пори року». У цих умовах можливо розглядати озеленені простори як місця для відпочинку громадян. Це

\section{БІБЛІОГРАФІЯ}

1. Докучаев В. В. Наши степи прежде и теперь / В. В. Докучаев. - М. : Сельхозгиз, 1953. - 152 с.

2. Малюга В. М. Принципи формування екологічної мережі України [Електронний ресурс] / В. М. Малюга, В. Ю. Юхновський // Лісове і садово-паркове господарство. - 2012. - №1. - Режим доступу : http://nbuv.gov.ua/UJRN/ licgoc_2012_1_10.

3. Екологічна мережа як шлях до відтворення екологічної стабільності [Електронний ресурс]. - Режим доступу : www.novaecologia.org/voecos316-4.html.

4. План действий - «Устойчивые Нидерланды». - М. : Экспресс, 1995. - 69 с.

5. Стойко С. М., Шеляг-Сосонко Ю. Р. Раритетний фітоценофонд України та концепція національної «Зеленої книги» // Український ботанічний журнал. - 2005. - 62, №5. - С. 611-623.

6. Олейниченко В. Д. Екологічна мережа як шлях до відтворення екологічної стабільності в першу чергу стосується маломобільних і незахищених прошарків населення, які в силу фізичних чи фінансових причин не можуть часто виїжджати за місто: людей похилого віку, інвалідів, матерів із маленькими дітьми, незабезпечених громадян. Що стосується доступності зелених зон, то більшість населення вважає, що живе більш-менш неподалік паркових зон, проте поняття «поряд» варіює в залежності від соціальної групи. Люди до 30 років вважають, що живуть поряд із парками значно частіше, ніж люди після 60 років, так як перші більш мобільні. Разом із тим, у зелених зонах формується особливе соціальне середовище, що включає в себе спілкування людей різних поколінь за інтересами, проведення культурних подій тощо. Парки i сквери міста $є$ одними 3 основних складових його комунікаційного простору. Забудувавши в межах району великого міста 2 га паркової зони, інвестор жодним чином не має можливості створити в цьому ж районі 2 га нового парку. Загибель насаджень відбувається внаслідок дії солі, якою знищується крига в зимовий період, внаслідок надмірного покриття вулиць і не потрапляння у землю атмосферних опадів, внаслідок перезабруднення атмосфери i внаслідок постійних обрізувань під виглядом формального благоустрою.

Висновок. Вважаючи екосистему прирічкового парку екологічно стабільною функціонуючою територією в умовах міста, важливим $є$ не тільки збереження біоценозу, а і резервування та подальше надання статусу як типово-унікальній екосистемі на основі показників стабільності.

[Електронний ресурс] / [Олейниченко В. Д.] // Збірник наукових статей «III-го Всеукраїнського з'їзду екологів 3 міжнародною участю». - Вінниця, 2011. - Том 1. - С. 233-236. - Режим доступу : http://eco.com.ua/.

7. Про Загальнодержавну програму формування національної екологічної мережі України на 20002015 роки. - Закон України // Урядовий кур'єр. 2000. - №37 ; Орієнтир. - 2000. - №207. - С. 3-16.

8. Закон України «Про екологічну мережу України» (ст. 3) м. Київ, 24 червня 2004 року N 1864-IV.

9. Бобра Т. В. Ландшафтные границы: подходы к анализу и картографированию / Т. В. Бобра. - Симферополь : Изд-во «Таврия-Плюс», 2001. - 165 с.

10. Денисик Г. І. Міжзональний геоекотон «лісостеп-степ» Правобережної України / Г. І. Денисик, О. І. Ситник. - Вінниця : ПП «ТД «Едельвейс і К», 2012. - 217 с. 